\title{
TIME IN FINNISH FOLK NARRATIVES
}

\section{Henni Ilomäki}

Some of us may recall the story about the Chinese man who asked the world-record sprinter how he would make use of the extra hundredth of a second he won in the race. Although we often talk about using our time wisely or foolishly wasting it, time is hard to reify; after all, in a way, time itself is non-existent - instead we have a process, movement, and change. We can only conceptualize time by comparing it with something else. Time is most easily described by measurement: years determine age; weeks and months make up the calendar year; as a stretch of time, the brevity of a nanosecond is just as inconceivable as the length of a geological era such as the Cambrian Period. The way we assess human achievements bears some relation to chronology.

These seemingly trivial aspects of time receive scientific attention in fields such as physics, philosophy and psychology. Our ability to perceive change is where our understanding of time begins. The psychological experience of time, i.e. the perception of changes, is determined by the synchronization of change sequences and intervals and duration. Many series of changes take place independently of the person who experiences them. Bodily rhythms are established by breathing, feelings of hunger or fullness, weariness or alertness; all of these act as markers of time. As people can physically adjust to daily and seasonal changes, they can also adjust to living by the clock and the calendar (Fraisse 1972: 25-28). Most of us find it relatively easy to adapt to official daylight savings time in the spring and fall. Time is also an experiential quantity: it may fly or crawl. While the past decade seems to have passed with astonishing speed, the decade that looms ahead may feel like a long way off.

If we define time as the fourth dimension, we can regard it as a spacial concept. Albert Einstein's theory of relativity challenged the notion of absolute time: even though the speed of light is an unchangeable quantity, the intervals between events depend entirely on the person who perceived them. Their mutual closeness or distance depends on the individual's position in the time con- 
tinuum. When we measure time in terms of distance, we think about speed: a three hour train journey takes the passenger from Berlin to Göttingen. The length of the journey is determined by our mode of travel.

Nowadays, the speed at which information travels is no longer bound by distance. Even at the beginning of this century printed news and rumors took at least a week to reach more remote regions. Today, in our age of instant information, modern communication networks can publicise events almost instantaneously regardless of location. Thus information techncology has also dramatically altered our concept of time.

Natural laws make little distinction between the past and the future. According to the law of thermodynamics, entropy grows with time in all closed systems. Thus defined time reveals the growth direction of information, in other words, people remember things in the order in which entropy grows. Thermodynamic time also determines psychological time, which distinguishes between the past and the future; after all, we can only remember the past, not the future (Hawking 1988: 144-145). Although it is theoretically possible for the future and the past to collide, it has yet to be scientifically recorded. An analagous possibility, however, does reside in the worldview of nonliterate societies: ritual communication takes place through myth in a timeless present. The archaic conceptual system tries to do away with time. According to Maurice Bloch, "it is a kind of phenomenological representation of time, where the present is a manifestation of the past: past in the present. It is a legitimation of temporal inequality by creating of mystified nature of concepts of time divorced or from everyday" (Bloch 1977: 288299). Claude Lévi-Strauss (1976) writes that a central feature of the syncretic concept of time is its cognitively static nature: myth needs time only to deny its place. Myth enables the illusion of immortality, and allows one to defer, if only briefly, an awareness of time. Mircea Eliade puts it like this: if people ignore time, its power is nullified, and the community can live in an everlasting present (Eliade 1993: 49-73). Here, the future and the past co-exist on equal terms. Jean Paul Sartre stated that the prevailing tense of the 20 th century novel to be le present eternel. Correspondingly, in his writing, James Joyce aspired to the eternal now (for more about concepts of time in modern culture, see lvanov 1973). 
Émile Durkheim initiated the anthropological reflections on the concept of time. According to him, time, like space, is collectively represented. As mental categories, time and space are communally determined. These categories influence how the individual interprets his/her experience of time. To apprehend time as something that passes requires an understanding of both the individual and collective experience of isolated units of time. In other words, to perceive the passage of time, a person needs units such as days, months, and years - and these units are communally defined. The outcome of this shared understanding is a calendar to regulate communal activities (Durkheim 1980: 33-40). The existence of a shared conceptual system, however, still allows room for personal interpretations.

\section{THE CONCEPT OF TIME TO DESCRIBE CULTURE}

Does time exist as a fixed cultural concept? It depends on how we choose to define time. Not all societies have an abstract concept of time (Goody 1972: 31). Many have argued whether or not the existence of a given concept can be proven only on linguistic grounds. According to E. R. Leach, a society whose language recognizes different layers of temporal definitions but has no word to denote time as an abstraction, lacks a clear concept of time (Leach 1971: 124, for critique see e.g. Alverson 1994: 5, Hallpike 1979: 343-344). A distinct concept for time is only established if there is a need for one. From a scholarly perspective, it makes more sense to make distinctions between elements of time than to meditate upon abstract time.

By taking note of repeated events, we measure time; the only thing that can not be repeated is an individual's life - which is terminated by death. These dichotomies - day and night, life and death can be likened to profane and sacred time (Leach 1971: 125-126, 134-136). The dichotomy refers to ways of thinking made manifest in cultural traditions. All cultures possess models of sequence and duration, cyclical or linear as well as units for counting time, they only differ in terms of their emphases. Practically speaking, a collective world view requires a sense of chronology based on the rotation of celestial bodies, the human life-cycle, personal use of time 
and future plans, as well as concepts of the past, present and future (Goody 1972: 30). Time is manifested in terms of action through different rhythms, and linguistically, for example, as grammatical forms and meaning.

Anthropologists have regarded a culture's overall sense of time as either cyclical or linear. The dichotomy is expressed in a variety of ways, particularly when it comes to cyclical time, which can be defined as ritualistic, non-continuous, structural, mythical, alternative, static, etc. Likewise, linear time is defined as durational, pragmatic, infrastructural or measurable.

The cyclical concept of time, which corresponds to the rhythms of the natural world, is often associated with non-literate societies. Cyclical time is allied with the sacred and linear time with the profane - and the notion of worldly progress. Cyclical and static time manifest themselves through ceremonies, even though the daily routines of the community conform to duration. All cultures make references to this, even though their temporal units may be different (Bloch 1977: 283-285). The repetitive nature of cyclical time is called into question particularly when it comes to the concept of death. When someone dies, the (experiential) end to an individual human life and the communal relationship to the event are placed in opposition: the bereaved re-establish their social relationship to the deceased through rites and the social symbols of the grave, etc. - the end of life is not absolute (Greenhouse 1996: 35 ). On the other hand, the custom of giving a child an ancestral name (Hämäläinen 1945) is in keeping with the notion of cyclical and repetitive time. Hence, the terminated time of one individual is then compensated by the birth of another member who will be integrated into the cycle of time.

The notion of time being culturally relative and conditioned has recently been criticized (e.g. Alverson 1994, Goody 1972, Valeri 1990, Östör 1993). The relevance of the conceptual apparatus has also been questioned: cyclical or repetitive time actually encompasses linear time, repeated events also take place in a certain order (Munn 1992). The difference between sacred and profane time is also visible in Western culture, the diachronic concept of time aided by literacy - lends support to the perception of longer periods of time. Sacred or liturgical time is still perceived according to 
the cyclical model (Goody 1972: 31). The profane celebrations of literate cultures generally also take place within annual cycles; on the other hand, according to creation myths, things have a temporal beginning and the oral genealogies of nonliterate cultures do take account of linear time. A Polynesian tribal ritual leads its participants backwards in time to the beginning. Thus the structure of social groupings and their interrelations were to a significant extent a function of time. The grand genealogy of the cosmos was a conceptual frame within which understandings of the natural and social worlds were linked in one encompassing idea. Genealogical time rules the chant" (Volland 1987: 113-134). The chronological concept is more linear than circular. We should recognize conceptions of time as parallelled and overlapping.

\section{CONCEPTUAL VARIATIONS OF TIME IN ORAL TRADITIONS}

The concept of time is a fundamental aspect of any given culture. The human awareness of time takes shape in the formation of intervals, the development of chronology, calculation systems, the conceptualisation of units of time, and in the use of images and metaphors (Howe 1981). Although cognitively static time could serve as an appropriate point of departure, other ways of thinking about time can also be traced in oral traditions. Examining observations from the field may prove helpful as we try to apprehend the logic of time-related expressions in Finnish folklore. The question can be approached in a number of ways: does the notion of chronology have anything to do with other ways of conceptualising time, or what is the relationship between time and space? What kinds of intervals in a tradition serve to produce time? Does time exist as a concept? What types of materials illustrate an awareness of duration? What forms of recognition have been granted to sequence? And where does timing fit in? Can folklore be the route to perceiving an awareness of time that is culturally-bound? Traditional terms for time from a body of folklore genres may not always be comparable as such, in other words, the material shedding light on ideas and functions may be fraught with contradictions. 
Although it is possible to lay bare the communal and individual characteristics of conceptions of time in theory, they can only be explored through their cultural manifestations, e.g., narratives about time. Just a few questions may be examined here.The study of popular notions of time requires us to define and name conceptual equivalents.

An anthropologist studying a culture other than his/her own collects material within the host culture through interviews and observation. The fieldwork may yield texts of oral traditions, free narration or comments on traditional lore, practices, and items of material culture. Based on his/her materials, the researcher constructs a picture of the communally accepted concepts, beliefs, and norms. Conclusions can also be drawn by making inferences from the various texts and descriptions of daily routines of work (cooking, hunting, e.g.) or trying to understand the significance of various practices. Even though the material gathered practically may reveal only a glimpse into the culture, the resulting ethnographic portrait may place too much emphasis on the homogeneous nature of the society, i.e., the anthropologist may have interviewed only a few individuals but through them he/she attempts to illuminate certain cultural characteristics. The anthropological fieldworker regards his/her entire body of material as part of the present experience of the informants: the past time of the myth is explained in the here and now.

The folklorist working in the archives grapples with another set of challenges. Archival data is made up of series of impressions collected from different informants at different situations and historical moments. The folklorist in the archives cannot go back in time to question the informant regarding his understanding of the qualifiers of time in the texts. Because the text lacks a living context, the names for units of time and their use often remain uncertain. In their search for traditional materials, the pioneers of European folklore studies sought to capture and render a picture of the past. Their attitude towards time was different from ours. Thus early folklorists were more intrigued by the content of folklore than in its significance as an element of communal knowledge. There was assumed to be a gap between the text and the performance: 
the performer's present moment faces the past tense of the narrative, in addition to criteria such as repetition and timelessness.

We can of course assume that the recorded texts of contemporary folklore can provide some commentary on the present moment of the narrator. For example, Ruth Finnegan has studied the influence of time in the construction and narration of an epic poem.

She has shown that the dimension of time in a performance - that is the structuring of pre-performance time, establishing a suitable time to perform the piece, use of time and timing, which are all necessary for a successful performance - is not evident in the collected text (Finnegan 1982). The relationship between the use of time and the performance nevertheless remains beyond the scope of this article.

\section{CONCEPTS OF TIME}

\section{Units}

Even though metaphors can describe the passage of time (folk poems depict a long time with an image of a grave overgrown with plant life: the shaman has been dead for so long that "on his chin is a wide grove / a willow clump on his beard / boat aspen on his shoulders"), to recognize and have a conceptual grasp of duration demands units of measurement. In an agrarian community what is most remarkable about the measurement of time is its ongoing cycle of similar periods; at the opposite end of the scale there is the mythical and timeless souls' time which coincides with the end of the agricultural year (Vahtre 1991: 12).

The cyclical concept of time follows the natural calendar: fall comes after summer, night follows day. A day is a natural starting point for pendulum clock time. Words to signify the moment preceeding the present or following day exist in many languages, but time passed or yet to come can also be expressed by counting the nights already slept or yet to be slept (Evans-Pritchard 1940: 102). Because their temporal units differ, time in the day is experienced differently from time at night. The entire night stands in opposition to the day, which unlike its opposition is divided into several 
periods, e.g., morning and afternoon. Night may commence after midnight and end when the cock crows; according to some wedding poems, this was an opportune time for a daughter-in-law to wake up. At the same time, as the workday begins, the time for the spirits to roam comes to an end. The motif is repeated in tales:

In the house of Marjaniemi it was customary to bathe late on Saturday night. Once again, the old woman of the house and a shepherdess were bathing late when an old devil with seven horns on his head entered the sauna ... The devil grabs the old woman, breaks her neck and shoves her into a crack in the wall. But the girl is beautiful, and the devil decides to take her with him... The girl says that she doesn't have her scarf or her shoes... and then the cock begins to crow and the demons cannot do anybody any harm once the cock has begun to crow. The devil must go home emptyhanded, and tell the folks back there that: "The boney mouth already began to scream, leather beard bellowed, and I didn't get my girl”. (Simonsuuri 1975: 255).

The week, originally invented in Mesopotamia, has been in use in Finland as either five or seven days (Harva 1939). It has been regarded as a unit in keeping with the rhythm of nature because it is closest to the synodic division of the month. The days of the week are categorised according to how much magical power is associated with each period. Narratives often thematically portray prohibitions on work which stress the contrast between profane and sacred time (Th C 630 1). Christianity has influenced Finnish narrative traditions:

A daughter from a well-to-do family went to collect berries on Sunday instead of going to church. After she had been collecting berries for a while a small gray-bearded guardian spirit appeared before her and asked the girl why she had gone to collect berries on Sunday instead of going to church. The girl replied, "So that I could get myself a pearl necklace." Then the guardian spirit threw a black snake around the girl's neck. And the snake has been around the girl's neck ever since. (Simonsuuri 1975: 324)

A year may signify the actual calendar year or simply a stretch of time. If time were not measured in a linear fashion, the year could have begun at any time. Unless linked to their seasonal labor, 
strictly established calendar dates were meaningless to peasants (Vahtre 1991: 45). Northern farming communities did not divide the year into four seasons, instead they divided the year into two parts: the time to sow and the time to harvest (Hiiemäe 1986: 9096, Niisson 1920: 54, Vahtre 1991: 31, Vilkuna 1961). As the day is to the night, the summer is to the winter, in other words, both day and summer hold more significance to those who live off the land, whereas in a hunting culture longer seasonal periods make sense (Vahtre 1991: 17-19, Vilkuna 1969: 16-17). As a unit of time, a single month meant little to the average peasant, but in the annual calendar certain months were important because of their place in the agricultural year: toukokuu (May) = sowing month, elokuu (August) $=$ harvest month. The calendar tradition both supported and relied on units of time.

\section{Timing}

Timing has been communally normative: agrarian cultures have been very particular about the right time for beginning a certain kind of task. People were also attentive to omens regarding the key phases of a human life by the calendar days, which were liminal periods in profane and sacred time (Hautala 1948). Certain moments were invested with magical significance. Failing to pay heed to such magical times was often a subject of ridicule in local tales and also a motif of narratives depicting nocturnal wanderings of the deceased on church lands.

In the old days it was customary for everybody - unless they were deathly ill - to go to church on Christmas morning. At the house of Mäkelä there was no clock... Mäkelä's old wife saw the gleam of bright flames and candles in the church. She thought that church service had already begun and went inside... The church was packed with people. After a moment, she saw a wife who had recently died. The wife came up to her and castigated the old wife for joining the congregation of the dead even though she was still alive. (Simonsuuri 1975: 119)

Even though a key feature of the above examples is the notion of falling out of step with ordinary time, the sequence of time remains undisrupted. 


\section{The Experience of Time}

Marcel Proust writes in his classic novel $A$ ' la recherche du temps perdu about the feeling after sudden awakening. You do not recognize your surroundings, and you seem to have been away for a long period, although the slumber lasted just a few seconds (Proust 1987: 5). Dream-time and common time are dissimilar.

Efficiency and speed are vital in today's technologically bound economy. Time is also valuable in day-to-day social relations as a resource and measure of achievement.

When a society's sense of time is contractual the individual's ability to apprehend the duration of time demands visible changes. As a person looks forward to an upcoming event, his/her mind establishes its own segment of time. This personal time between the present moment and the moment his plans will be realized is detached from the communal rhythm. Understanding time requires symbolic interaction, which is used by the remembering mind. Individual interpretations of time are subject to variation. Although communal and individual time are not always commensurable, sharing the conceptual world of the community requires a certain interpretative uniformity (Coulon 1995), as communication is based on socially defined and understood symbols. The dual levels of time in folktales can function as supernatural criteria. A short time may be experientially long. For example, the maid in the church at night trying to make peace between a killer and his victims was convinced that "she had been in the church for many hours, because the time seemed to have gone so slowly for her," while the others were amazed at how quickly she had dealt with such a difficult task (Simonsuuri 1975: 123). Felix Karlinger regards this as one type of experience of time, whereas another type, a seemingly short period of time, may in reality take a long time (Karlinger 1986).

Two young men promised to attend each other's weddings. One of the men died. When the other young man was about to be married, he went to the graveyard to invite his friend to his wedding. A voice called from the grave: "Take three handfuls of earth, and then I can join you". The groom did has he was told and his friend came to the wedding. In the end, the groom escorted his friend back to the graveyard, but when he heard the fun the dead 
had among themselves, he decided to take a look. After spending only a moment at this party, he heard a voice urging him: "Go dear man, you have already been sitting here for fifty years". Finally, 'after one hundred years' when he returned to his home, he could no longer recognize any of the once familiar places. (Simonsuuri 1975: 89-90)

Likewise, a long journey may last only a moment: a tale depicting a farmer's journey to Lapland in search of a knife is a good example. His trip home is speeded up thanks to witchcraft, it was the speed of the human mind. He came home with such alacrity that he didn't have even time to warn the folks at home of the price he paid for getting home so fast, hence the sudden disappearance of the black bull he had promised in return (Simonsuuri 1975: 205).

The following short poem also measures speed. According to the little verse, a witch or a supernatural being, compelled by the crow of the cock, moves so quickly that it simultaneously heard sounds from several far-off places (Honko 1958):

The cock crows in Kuurinmaa

The hen clucked in Estonia

The swine whined in Vyburg

The piglet squealed in Porvoo

The bull bellowed in Hämenmaa

Thus time is described differently from our conventional experience of time. The strangeness of the experience is underlined when the sequence of temporal units is altered.

\section{INTERSECTING LEVELS OF TIME}

Sometimes the intervals between events appear to be disrupted or the chronology of events differ from the expected. Overlapping time is linked to the overlapping of the real and the mythical. Some folk narratives, like the following memorate, illustrate how an event or a person is foreseen:

Once a man driving a carriage paid a visit to a manor house. He drove into the yard, secured his horse, and then fed and watered the beast. When someone from the house went to take a look at 
the identity of the visitor, there was no-one to be seen. After a little while, another identical horse appeared and another man did the same thing as did the previous carriage driver. When the man was asked about this, he said that the earlier man was his doppelgänger (spiritual double) and always travelled ahead of him. (Simonsuuri 1975: 11)

Correspondingly, a nocturnal guest is identical to somebody who later appears with the news of another person's death (Simonsuuri 1975: 15). The tale motifs about the death omens coming true allude to the notion that one's life span is predetermined; and no deals can be arranged to extend one's time on earth. According to the international tale motif, a man who heard that he was destined to drown and did his utmost to dodge a watery death, eventually hears the river say: "The time has come, but not the man". The man thus induced to drown himself (Th D 1311. 11.1). Here the cyclical understanding of time is punctured by a keen awareness of a fixed segment of time in the continuum.

Finnish folk belief tells us that although virtually anyone can identify an omen, interpretation, like predicting the future, required the unique insight of a specialist. In traditional communities, an omen that has come true takes us into the realm of the supernatural. During liminal periods in the calendar year, however, even an ordinary layman may transcend temporal continuity:

Once the servant of a priest had heard that if during midsummer night she went to wash her shirt by the river while naked, she would see her future husband. One Midsummer night she went to the river bank, undressed herself and began to wash her shirt while she was stark naked. Then she saw the pastor walking on the other side of the river. She thought that it was the actual pastor and was filled with shame. Then, the priest fell in love with his servant and before the year was over, the two of them were married. Only later did the young wife tell her husband about seeing him the previous Midsummer, and she learned that it was not the pastor walking along the river, but his doppelgänger (spiritual double). (Simonsuuri 1975: 35)

The tripartite division of time plays a fundamental part in Indoeuropean culture. The place from which we perceive time is the present moment, which is preceded by the past and followed by 
the future. Their relationship is nevertheless far from ambiguous: in the past, after all, the present moment was the future and in the future it will belong to the past. All that we know and are able to examine today is already a thing of the past (Toulmin \& Goodfield 1967: 18).

The future and the past are not empirical concepts. According to Boris Uspenski, the future is a text which has yet to be read. The relationship between different times can function as a model of the bond between the present and the future. Overlapping time becomes authenticated when a memorate's auditory observations of an individual's return are made twice - first mistakenly and then in an identical way when the person actually appears. The mythical compression of time is actually one of the supernatural criteria for the event. The element of duration disappears, the law of sequence loses its meaning. A prolonged present is born. In the same way ritual communication happens through myth in a timeless present.

The overlapping interpretation of the past, present and future provides a basis for not only prophesy but also planning. The human brain can not only perceive past time, memories, but also what lies ahead, the future. A vital function of the brain is to predict what will happen next. A person needs prescriptive advice regarding the future, but he/she wants to know even more. Making predictions is based on information already acquired about the past, which serves as a counterbalance to entropy. Then "the time arrow turns from the future using the mold of the past" (Ivanov 1973: 8-12, 15-17).

Predicting the future and dreams about carrying out future plans are based on the same need as that of observing omens on significant calendar days or beginning important tasks according to favorable signs. These are attempts at unraveling the mysteries of the future.

\section{THE FUTURE}

Finnish folk fantasies of the unknown future have been verbalised in narratives about technical inventions. These tales are accounts of the land being girded up with iron bands, horses without heads 
or tails charging down the roads, huge squares peering out of buildings, etc. These fantasies have apparently been influenced by obscure stories and rumors about railroads, cars, glass windowpanes, etc. The international horror stories of the future predict the end of the world - as the aftermath of war, the crossroads are so flooded with blood that a heavy log can be spun about in the eddy (Simonsuuri 1951: 229-230). The strange behavior of birds (Th B 143.2) or the Sun or Moon shining at the wrong time (Th A 10053. 1,1052.2) are world famous as signs of the day of reckoning. Horrific apocalyptic visions assumed a literary form a long time ago. Precise dates are presented in a prediction dating from 1731, which begins with the earthquake of 1755 and ends with the dimming of the stars in 1999. Nostradamus' predictions, however, are metaphorical and are open to interpretation (Devlin 1987). Popular images of the end of the world are timeless yet concrete and detailed. The end of the world, according to a Finnish soothsayer, would come when "The long peninsula of Tuusniemi is broken by the water of Juovesi." On the other hand, in legends popular heroes wait asleep for the time they are needed to save their people from a future danger.

Not even literacy has alleviated fears of the future. In the West people try to minimise the impact of future accidents by taking insurance; horoscopes are actively read, and celebrities and ordinary people seek answers from fortune tellers. Why some religious communities have such a powerful hold on their members stems partly from uncertainty about the future.

Today people find themselves thinking about the end of the millenium, we can see its impact in terms of the activities of some religious sects. Some regard the chaotic situation facing computer programs at the end of the millenium as proof of the wickedness of virtual reality. There is a database in the Internet (http:// www.cpsr.org/program/y2k/) maintained by CPSR that collects rumours and predictions concerning the year 2000. The list includes estimations concerning economical catastrophes, aviation accidents, problems in medical care, etc. Crafty people make use of other people's fears. In his book "Questioning the Millennium" Stephen Jay Gould, professor of zoology at Harvard University, reports for instance about huge investments by the British government - for building a Millennium Dome at Greenwich. 
When trying to control the ever-enigmatic future, people try to make real their fears and desires for the future. Such thinking can serve to inspire, but it is still essential to have a durable moral code: no one sets goals that are potentially dangerous to the society, instead horrific visions serve to guide present behavior. The predictions couched in traditional narratives served, too, as warnings to the sinful or the frivolous-minded.

Obviously, no matter how hard we try the future is unpredictable; for example, after the Second World War, the pace of technological development in the West was assumed to take place much faster. Dreams of conquering outer space have been shown to be excessively optimistic. In cities, people continue to walk along streets; only airports have moving sidewalks. In the past, people saw no hope for recovery from ecological destruction. Nowadays there are plans to conserve the environment, and we are able to assess the span of development with much less hysteria. As we seek to know about the future, we are often unaware of the concept of time. In the realm of science fiction, however, anything can happen, and the most daring would like to to be put into the deep freeze to skip the present time in favor of waking up to a new life in the future.

In the end there seems to be no difference between traditional and modern attitude towards the time, especially the future. However, the argumentation and expression differ. When the tradional man estimated the future according to similarities in the past, the modern man calculates: he counts the periods and phenomena and makes his deductions according to them. Even the idea of the millennium is due to arithmetic operation. Cyclical time really seems to be different from linear.

\section{References}

Alverson, H. 1994. Semantics and Experience: Universal Metaphors of Time in English, Mandarin, Hindi and Sesotho. Baltimore \& London.

Bloch, M. 1977. The Past and Present in Present. Man 12.

Coulon, A. 1995. Ethnomethodology. London \& New Delhi.

Devlin, J. 1987. The Superstitious Mind. French Peasants and the Supernatural in the Nineteenth Century. New Haven \& London. 
Durkheim, É. 1980 (1914). Uskontoelämän alkeismuodot. Australialainen toteemijärestelmä. Helsinki \& Tammi.

Eliade, M. 1993. Ikuisen paluun myytti. Kosmos ja historia. Helsinki.

Evans-Pritchard. 1940. The Nuer. A Description of the Modes of Livelihood and Political Institutions of a Nilotic People. Oxford.

Finnegan, R. 1982. 'Short Time to Stay': Comments on Time, Literature and Oral Performance. Hans Wolff Memorial Lecture. Indiana, Indiana University: African Studies Program.

Fraisse, P. 1972. Time: Psychological Aspects. International Encyclopedia of the Social Sciences, Vol. 15. New York \& London.

Goody, J. 1972. Time: Social Organization. International Encyclopedia of the Social Sciences, Vol. 15. New York \& London.

Greenhouse, C. 1996. A Moment's Notice. Time Politics across Cultures. Ithaca \& London.

Hallpike, C. R. 1979. The Foundation of Primitive Thought. Oxford.

Harva, U. 1939. 'Mikko' vanhissa runoissamme. Virittäjä, 43.

Hautala, J. (ed.) 1948. Vanhat merkkipäivät. Suomalaisen Kirjallisuuden Seuran toimituksia, 229. Helsinki.

Hawking, S. H. 1988. Ajan lyhyt historia. Alkuräjähdyksestä mustiin aukkoihin. Helsinki.

Hiiemäe, M. 1986. Aastajaotustähistest eestlaste rahvakalendris. Keel ja Kirjandus 2.

Honko, L. 1958. Nopeuden mensuraaleja kansanrunossa. Kalevalaseuran vuosikirja 38 .

Howe, L. E. A. 1981. The Social Determination of Knowledge: Maurice Bloch and Balinese Time. Man 16.

Hämäläinen, A. 1945. Über die Namengebungsbräuche bei den Mordwinen und Tscheremissen. Mitteilungen des Vereins für finnische Volkskunde. Helsinki.

Ivanov, V. 1973. The Category of Time in Twentieth-century Art and Culture. Semiotica 8.

Karlinger, F. 1986. Zauberschlaf und Entrückung. Zur Problematik der Jenzeit in der Volkserzählung. Raabser Märchen-Reihe 7. Wien.

Leach, E. R. 1971. Two Essays Concerning the Symbolic Representation of Time. Rethinking Anthropology. (London School of Economics. Monographs on Social Anthropology, 22). New York. 
Lévi-Strauss, C. 1976. The Savage Mind. (La penseé sauvage) London.

Munn, N. H. 1992. The CulturalAnthropology of Time: A Critical Essay. Annual Review of Anthropology 21.

Nilsson, M. P. 1920. Primitive Time-Reckoning. Skrifter, 1. Lund.

Proust, M. 1987. A la recherche du temps perdu. Paris.

Simonsuuri, L. 1951. Kotiseudun tarinoita. Suomalaisen Kirjallisuuden Seuran toimituksia, 229:3. Helsinki.

Simonsuuri, L. (ed.) 1975. Myytillisiä tarinoita. Helsinki.

Thompson, S. 1958. Motif-Index of Folk-Literature. Copenhagen.

Toulmin, S. \& Goodfield, J. (eds.) 1967. The discovery of time. London.

Vahtre, L. 1991. Eestlase aeg. Uurimus eesti rahvapärase ajaarvamise ajaloost. Tallinn.

Valeri V. 1990. Constitutive History: Genealogy and Narrative in the Legitimation of Hawaiian Kinship. Culture through Time: Anthropological Approaches. Ed. by Emiko Ohnuki-Tierney. Stanford.

Vilkuna, K. 1961. Wochenrechnung und Teiling des Jahres in zwei oder vier teile. Finnisch-ugrische Forschungen 34. Helsinki.

Vilkuna, K. 1969. Finnisches Brauchtum in Jahreslauf. FF Communications 206. Helsinki.

Volland, A. 1987. Metaphors of Time: Symbolic Dimensions of Polynesian Staff Images. Mirror and Metaphor: Material and Social Constructions of Reality. Ed. by Daniel Ingersoll Jr. and Gordon Bronitsky. Boston.

Östör, A. 1993. Vessels of Time. An Essay on Temporal Change and Social Transformation. Delhi. 